\title{
МОНИТОРИНГ ЭПИЗООТИЧЕСКОЙ СИТУАЦИИ ПО ПРОТОЗООЗАМ В ЗВЕРОХОЗЯЙСТВАХ КАЛИНИНГРАДСКОЙ ОБЛАСТИ (2018-2020 ГОДЫ)
}

\author{
Ю.Е. КУЗНЕЦОВ ${ }^{1}{ }^{凶}$, Л.М. БЕЛОВА ${ }^{1}$, Н.А. ГАВРИЛОВА ${ }^{1}$, Н.В. КУЗНЕЦОВА ${ }^{1}$, \\ А.Б. МУРОМЦЕВ 2 , А.Ю. ЕФРЕМОВ 3
}

Паразитарные болезни широко распространены у пушных зверей, особенно у норок (Mustela vison Linnaeus, 1761, Neovison vison Schreber, 1777). Кокцидиидозы среди инвазионных болезней занимают особое место, так как часто протекают без выраженных симптомов, что затрудняет их своевременную диагностику. Несмотря на слабо выраженное клиническое проявление инвазии, кокцидии причиняют серьезный вред здоровью животных и наносят ощутимый экономический ущерб звероводческим хозяйствам. Анализ литературных данных показал, что распространение эймериидозов пушных зверей в Калининградской области изучено недостаточно. В частности, отсутствует информация об экстенсивности и интенсивности инвазии, а также возрастной динамике эймериидозов норок в звероводческих хозяйствах этого региона. Цель настоящей работы - изучение эпизоотической обстановки по эймериидозам норок в трех звероводческих хозяйствах Калининградской области. Видовой состав простейших у норок определяли с помощью анализа морфологических признаков кокцидий и методом глубокого секвенирования региона V4 гена 18S pРНК. Проведенный биоинформатический анализ позволил определить ОТЕ (операционные таксономические единицы), установить таксономическую принадлежность возбудителей и подтвердить результаты световой микроскопии. При анализе результатов, полученных в ходе экспериментов и выборе методов исследований, учитывали возраст, пол животных, а также условия их кормления и содержания. Объектами исследования был молодняк норок 5-6-месячного возраста и взрослое поголовье - самки и самцы в возрасте 1-2 года. Всего во всех трех хозяйствах обследовали 561 особь (общее число животных - зараженных и интактных). Во всех обследованных хозяйствах у норок обнаружили простейших семейства Eimeriidae. Наиболышая экстенсивность инвазии (56\%) и самое широкое видовое разнообразие кокцидий было установлено в звероводческом хозяйстве, находящемся в Багратионовском районе Калининградской области. Паразитофауну норок, содержащихся в этом зверохозяйстве, представляли два вида эймерий (Eimeria vison и E. furonis) и два вида изоспор (Isospora laidlawi и I. eversmanni; вид I. eversmanni ранее был впервые выявлен нами у норок в Калининградской области). Эймериидозы у норок во всех звероводческих хозяйствах чаще диагностировали в форме моноинвазии. Процентное соотношение микстинвазий было следующим: микстинвазия двумя видами паразитов $-68,55 \%$, микстинвазия тремя видами паразитов $-23,67$ \%. Подтверждено, что молодняк норок более подвержен эймериидозам, чем взрослые животные. У животных текущего года рождения наиболее часто встречаются $E$. vison $(18,36 \%)$, I. laidlawi $(16,32 \%)$ и E. vison + I. laidlawi $(11,90 \%)$.

Ключевые слова: Mustela vison, Neovison vison, норки, Eimeria vison, Eimeria furonis, эймерии, Isospora laidlawi, Isospora eversmanni, изоспоры, моноинвазия, микстинвазия, экстенсивность инвазии, интенсивности инвазии, зверохозяйства, Калининградская область.

Пушные звери, содержащиеся в звероводческих хозяйствах, часто подвержены различным инфекционным и инвазионным болезням (1-3). Плотоядные, содержащиеся в неволе, особенно при клеточном содержании, нередко инвазированы кишечными простейшими. Анализ научных публикаций показывает, что в России, как и в других странах, норки заражены преимущественно простейшими из семейства Eimeriidae Munchin, 1903 (46). Исследователи отмечают наибольшую восприимчивость к эймериидозам молодняка норок 2-3-месячного возраста, среди которого зараженность достигает $68 \%(7-9)$.

Болезни паразитарной этиологии наносят ощутимый экономический ущерб мировому пушному звероводству (3, 10-12). В патогенезе эймериидозов важное место занимает нарушение целостности слизистой оболочки кишечника у больных норок, что обусловлено прохождением эндогенной стадии биологического цикла развития паразита (мерогонии), вследствие чего возникают патологические изменения морфологической 
структуры слизистой тонкого кишечника. Воспалительный дендрит, развивающийся в процессе десквамации эпителия, и продукты жизнедеятельности простейших, создают условия для проникновения и размножения вторичной микрофлоры. Из-за катарально-геморрагического энтерита и некроза кишечника организм не усваивает питательные вещества, животные худеют и возможен летальный исход (13-15). Эймерии относятся к строго специфичным паразитам, при этом паразитируют у животных разных систематических групп $(1,5,8)$.

Исследования, проведенные группой ученых на датских фермах в период с апреля по октябрь 2016 года, показали, что из 4140 обследованных животных зараженными оказалось 108 , следовательно, экстенсивность инвазии (ЭИ) составила 2,6 \%. Морфологический анализ спорулированных ооцист $(n=20)$, проведенный методом световой микроскопии, позволил установить их видовую принадлежность к роду Eimeria. Размеры ооцист составляли $21,0 \times 13,8$ мкм с отношением длины к ширине (L/W) 1,5. На сегодняшний день вопросы видовой принадлежности эймерий в ряде случаев дискуссионны. Только молекулярно-генетические исследования и филогенетический анализ последовательностей $18 \mathrm{~S}$ рРНК (1221 п.н.) образцов, полученных от зараженных норок, позволили установить, что $E$. vison представляет собой вид, обладающий наибольшим генетическим сходством с Eimeria sp., впервые выделенным от полосатой полевой мыши (Apodemus agrarius) в Чешской Республике. Анализ более короткой области $18 \mathrm{~S}$ pPHK (531 п.н.) показал, что последовательности генома E. vison имеют 97,7 \% сходства с другим видом - E. furonis (16). Полученные Н.H. Petersen с соавт. (16) данные могут свидетельствовать о том, что E. vison и E. ictidea - вероятно, один вид, так как они имеют высокое морфологическое и генетическое сходство. Таким образом, решить вопрос о таксономической самостоятельности того или иного вида эймериид возможно только при комплексном молекулярно-генетическом исследовании $(16,17)$.

Эпизоотическая ситуация по эймериидозам в регионах России неодинакова, а в ряде областей требует дополнительного исследования $(7,18)$. Анализ специальной литературы показал, что распространение эймериидозов пушных зверей в Калининградской области изучено недостаточно, в частности отсутствует информация об экстенсивности и интенсивности инвазии, возрастной динамике эймериидозов норок в звероводческих хозяйствах (19).

В настоящей работе представлены результаты проведенного впервые за многие годы мониторинга эпизоотической ситуации по протозоозам в звероводческих хозяйствах Калининградской области. Определены интенсивность и экстенсивность инвазии кокцидиями у норок разных возрастных групп. С использованием секвенирования и анализа гена малой субъединицы рибосомальной PHK (SSUrDNA) выполнена идентификация паразитофауны норок.

Цель работы - изучение эпизоотической обстановки по эймериидозам норок в звероводческих хозяйствах Калининградской области.

Методика. Исследования проводили в период с 2018 по 2020 год в трех звероводческих хозяйствах Калининградской области на норках (Mustela vison Linnaeus, 1761, Neovison vison Schreber, 1777) (молодняк 5-6-месячного возраста и взрослое поголовье самок и самцов в возрасте от 1 до 2 лет). При выборе методов исследований и анализе полученных данных учитывали возраст, пол животных, а также условия кормления и содержания.

Всего за период наблюдения обследовали 561 норку (зараженные эймериидами и интактные), включая 267 взрослых животных (115 самцов и 152 самки) и молодняк (294 особи). В зверохозяйстве № 1 выборка соста- 
вила 273 зверька, из них молодняка - 198, взрослых животных -75 особей (33 самца и 42 самки); в зверохозяйстве № $2-160$ норок, из них молодняка - 68, взрослых животных - 92 (44 самца и 48 самок), в зверохозяйстве № $3-128$ норок, из них молодняка -28 , взрослых животных -100 (44 самца и 56 самок).

Свежевыделенные пробы фекальных масс (по 10-20 г) от обследуемых норок помещали в индивидуальную тару, этикетировали и доставляли $\left(\right.$ при $\left.+2-8{ }^{\circ} \mathrm{C}\right)$ в лабораторию для исследований.

Ооцисты эймериид выделяли из фекальных масс методом Дарлинга с использованием универсальной флотационной диагностической жидкости (20). Полученный материал просматривали в световом микроскопе Микротон-200М (ООО «Петролазер», Россия), используя насадку Микрометр ОМП ЛОМО (АО «ЛОМО», Россия) и микроскопе Primo Star («Carl Zeiss», Германия) с визуализацией при увеличении $(10 \times 10,10 \times 20$ и 10×40). Фоторегистрацию осуществляли при помощи фотокамеры микроскопов и камеры смартфона Mi MIX 2 («Xiaomi», Китай). При определении вида паразита обращали внимание на размер ооцист, их форму, цвет, толщину оболочки, наличие или отсутствие микропиле, остаточного тела, полярной гранулы, определяли индекс формы (соотношение длины к ширине).

Ооцисты эймериид культивировали по методу Арнастаускене (1985) с использованием 2 \% раствора бихромата калия $(3,20)$. Ооцисты после концентрирования и отмывания помещали в усовершенствованные чашки Петри и инкубировали в термостате при температуре $25-28{ }^{\circ} \mathrm{C}(21)$, ежедневно просматривая под микроскопом при увеличении $(10 \times 10$ и $10 \times 40)(9$, 18) для определения сроков споруляции.

Интенсивность инвазии оценивали подсчетом ооцист эймериид в 1 г фекалий, используя счетную камеру ВИГИС (ВИГИС, СССР). Определяли таксономическую принадлежность простейших, руководствуясь описанием их морфологических характеристик в монографии L.P. Pellerdy (22). Экстенсивность инвазии оценивали при флотационном исследовании проб фекалий по Дарлингу как процент инвазированных образцов от числа обследованных животных.

Для подтверждения видового состава кокцидий использовали метод секвенирования и проводили филогенетический анализ гена малой субъединицы рибосомальной PHK (SSUrDNA).

Для выделения ДНК использовали по 10 образцов фекалий от разных животных. Отмытые ооцисты морфометрировали и подвергали 3-кратному замораживанию в жидком азоте $\left(-196^{\circ} \mathrm{C}\right)$ для разрушения стенок и высвобождения спороцист. Экстракцию и очистку геномной ДНК проводили согласно описанию (23-25). Концентрацию полученной ДНК оценивали на спектрофотометре SS2107 («MEDIORA OY», Финляндия), препараты хранили при +4 или $-20^{\circ} \mathrm{C}(23)$.

Каждый образец генотипировали по двум локусам - ядерной $18 \mathrm{~S}$ рДНК (SSUrDNA) (26) и субъединицы I митохондриальной цитохромоксидазы (mt COI) (27). Области из nu 18SSUrDNA и митохондриальной ДНК субъединицы I цитохромоксидазы (mt COI) амплифицировали с помощью полимеразной цепной реакции (ПЦР). Для всех образцов ПЦР-амплификацию в реальном времени проводили на Veriti® Thermal Cycler («Life Technologies, Inc.», США) в объеме 25 мкл, содержащих 100 нг геномной ДНК, $1 \times$ ПЦР-буфер, 1,5 мM MgCl2, 0,2 мM dNTPs, 1 ед. полимеразы TaqDNA Invitrogen Platinum («Thermo Fisher Scientific», Канада) и 400 нМ каждого праймера $(28,29)$. При секвенировании ПЦР-фрагменты получали в термо- 
циклере Bio-Rad T100 («Bio-Rad Laboratories», Сингапур). Режим амплификации: 3 мин при $95{ }^{\circ} \mathrm{C}$; 30 с при $94{ }^{\circ} \mathrm{C}$, 30 с при 56-62 ${ }^{\circ} \mathrm{C}, 30-75$ с при $72{ }^{\circ} \mathrm{C}$ (35 циклов); 7 мин при $72{ }^{\circ} \mathrm{C}$ (финальная элонгация). Полученные продукты амплификации разделяли электрофорезом в $2 \%$ агарозном геле, окрашивали бромидом этидия, визуализировали на ультрафиолетовом трансиллюминаторе WUV-M10 («DAIHAN Scientific», Южная Корея) и разделяли с помощью электрофореза в агарозном геле с флуоресцентной детекцией. Далее их анализировали с использованием автоматического секвенатора CEQ 8000 («Beckman Coulter», США) согласно рекомендациям производителя. Погрешность прибора CEQ 8000 составляла не более $5 \%$ (23). Результаты учитывали по размеру и площади пиков с помощью программного блока в базе данных Geneious (https://www.geneious.com/), таксономическую аннотацию эймериид проводили средствами поиска BLAST (https://blast.ncbi.nlm.nih.gov/Blast.cgi) с использованием опубликованных в GenBank нуклеотидных последовательностей (https://www.ncbi.nlm.nih.gov/genbank/) (23-25, 28). Филогенетический анализ проводили с помощью программы Molecular Evolutionary Genetics Analysis (MEGA v. 7.1) $(30,31)$.

Статистическую обработку результатов выполняли в программах Microsoft Excel 2013 и Primer of Biostatistics 4.03 for Windows.

Результаты. Мониторинг инвазированности и состава паразитофауны норок важен для определения их фактической роли в передаче паразитарных зоонозов (32). В зверохозяйстве № 1 (Багратионовский р-н, Калининградская обл.) инвазию эймериидами установили у 153 норок из 273 обследованных (ЭИ = 56 \%). Мы обнаружили два вида эймерий $-E$. furonis и E. vison (рис. 1, а) и два вида изоспор - I. laidlawi и I. eversmanni (см. рис. 1, б).
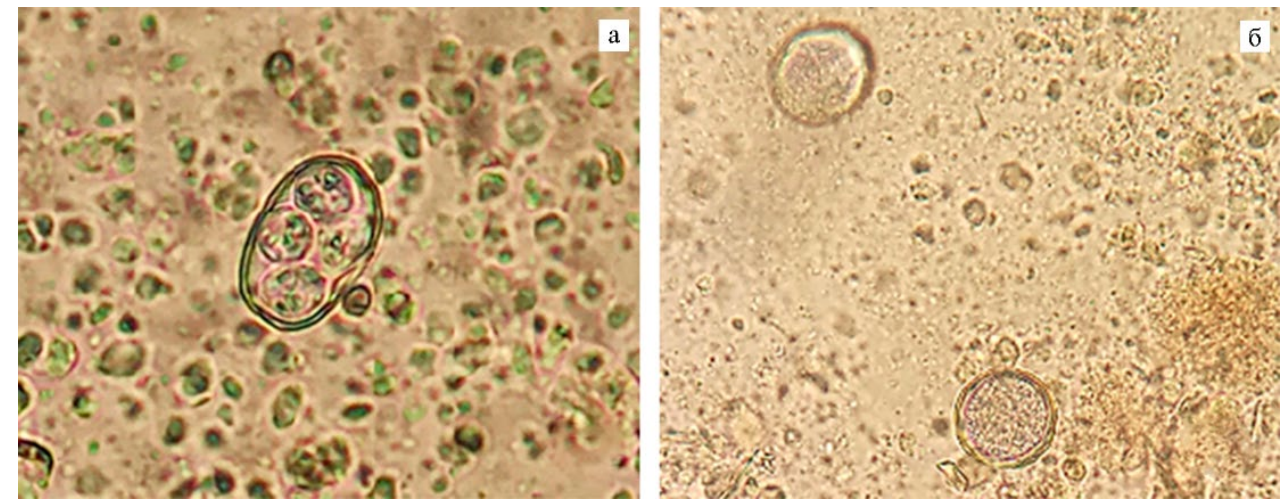

Рис. 1. Световая микроскопия ооцист эймериид, выделенных от норок (Mustela vison) в зверохозяйствах (Калининградкая обл., 2018-2020 годы): а - спорулированная ооциста Eimeria vison (увеличение $\times 1480$ ), б - неспорулированные ооцисты Isospora laidlawi + I. eversmanni (увеличение ×1280) (Микротон-200M, ООО «Петролазер», Россия).

1. Пары праймеров для амплификации ядерного и митохондриального локусов (24-26), использованные при генотипировании эймериид в образцах от норок (Neovison vison) из обследованных звероводческих хозяйств (Калининградкая обл., 2018-2020 годы)

\begin{tabular}{|c|c|c|c|}
\hline Локус & $\begin{array}{l}\text { Название } \\
\text { праймера }\end{array}$ & Последовательность (5' $\left.\rightarrow 3^{\prime}\right)$ & Автор \\
\hline 18S pPHK & $\begin{array}{l}\text { V4F } \\
\text { V4RB }\end{array}$ & $\begin{array}{l}\text { CCAGCASCYGCGGTAATTCC } \\
\text { ACTTTCGTTCTTGATYRR }\end{array}$ & $\begin{array}{l}\text { S. Balzano c coaBT. } \\
(2015)\end{array}$ \\
\hline $\mathrm{mt} \mathrm{COI}$ & $\begin{array}{l}\text { COI_10F } \\
\text { COI_500R }\end{array}$ & $\begin{array}{l}\text { GGWDSWGGWRYWGGWTGGAC } \\
\text { CATRTGRTGDGCCCAWAC }\end{array}$ & $\begin{array}{l}\text { J.D. Ogedengbe c соавт. } \\
\text { (2011) }\end{array}$ \\
\hline
\end{tabular}

Видовой состав простейших у обследованных норок был подтвер- 
жден методом метагеномного секвенирования (рис. 2) со следующими праймерами (табл. 1) (28).

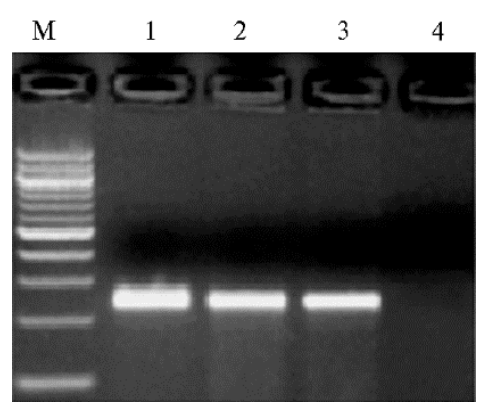

Рис. 2. Пример электрофоретического анализа $18 \mathrm{~S}$ рДНКбиблиотек при генотипировании эймериид, выделенных от норок в звероводческих хозяйствах Калининградской области (2018 год): M - маркер молекулярных масс (GeneRuler $1 \mathrm{~kb}$ Plus DNA Ladder, «Thermo Fisher», США), 1-3 - анализируемый образец Nor1 (Eimeria vison) при разном количестве ДНК (1, 2, 3 мкл), 4 - Ctrl_NegControl (2 \% агарозный гель).

При молекулярном анализе нуклеотидной последовательности гена рибонуклеиновой кислоты малой рибосомальной субъединицы была установлена видовая принадлежность выделенных возбудителей эймериидозов. Глубокое секвенирование региона V4 гена $18 \mathrm{~S}$ рРНК и биоинформатический анализ позволили определить ОТЕ (операционные таксономические единицы) и установить их принадлежность. По результатам генотипирования, преобладающими видами простейших, паразитирующих у норок, были E. vison, E. furonis, I. laidlawi, редко встречающимся видом - I. eversmanni (25). Последовательность фрагмента $18 \mathrm{~S}$ рДНК длиной 383 п.н., выявленная в ооцистах, которые по результатам световой микроскопии мы отнесли к виду E. vison, имела наибольшее $(99,48$ \%) сходство с последовательностями E. ictidea (25). Последний вид ранее не был обнаружен нами при копроовоскопии под световым микроскопом ни в одном из обследованных зверохозяйств. Этот результат свидетельствует о том, что требуются более подробные молекулярно-генетические исследования эймериид с использованием более длинной нуклеотидной последовательности. Высокое морфологическое и генетическое сходство $E$. vison и $E$. ictidea ставит вопрос о возможной необходимости синонимизации этих двух видов (9). В то же время проведенный нами филогенетический анализ и построение комбинированного древа, основанного на сравнении последовательности фрагмента $18 \mathrm{~S}$ рДНК длиной 383 п.н. образца OTU 213, указывает на то, что E. ictidea - это все же, скорее всего, самостоятельный вид эймерий, который отличается от E. vison, если судить по нуклеотидным последовательностям, опубликованным в GenBank (https://www.ncbi.nlm.nih.gov/genbank/) (рис. 3).

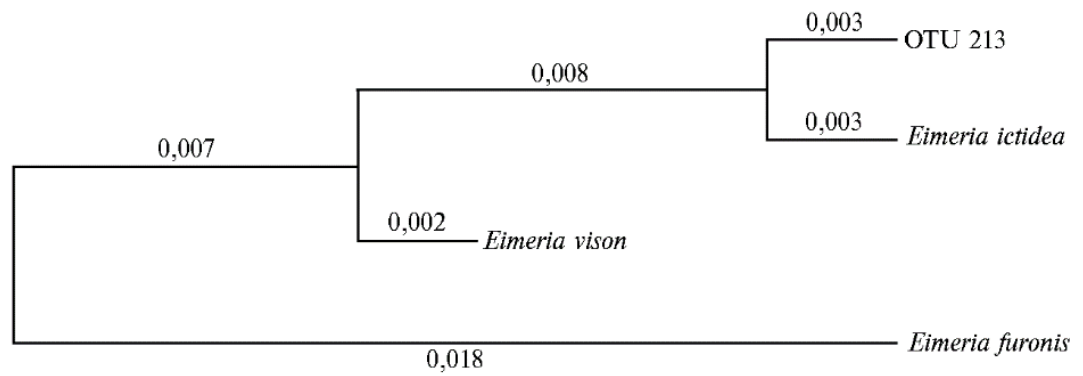

Рис. 3. Филогенетический анализ (комбинированное древо) видов эймериид, выполенный на основе нуклеотидной последовательности фрагмента 383 п.н. 18S рДНК. Образец ОТU 213 выделен от норок в звероводческом хозяйстве Калининградской области в 2019 году; нуклеотидные последовательности Eimeria vison, E. furonis и E. ichdea опубликованы в GenBank (https://www.ncbi.nlm.nih.gov/genbank/).

Результаты проведенного нами генотипирования на основе анализа ядерной $18 \mathrm{~S}$ рДНК SSUrDNA (с подтверждением по mt COI) также указали 
на циркуляцию в обследованных хозяйствах двух видов эймерий E. furonis и E. vison и двух видов изоспор - I. laidlawi и I. eversmanni, которые были обнаружены при световой микроскопии. Следует отметить, что у $E$. vison Kingscote, 1934 ооцисты имеют морфологическое сходство с другим видом эймерий - E. ichdea Hoare, 1927, то есть только с помощью световой микроскопии (морфометрически) дифференцировать их довольно сложно. По результатам проведенной нами морфометрического описания у вида E. vison размеры ооцист 16,3-27,7 мкм (длина)×11,6-18,54 мкм (ширина), в среднем 22,0×15,07 мкм, индекс формы 1,46. Микропиле отсутствует. Зигота мелкозернистая, шаровидно-вытянутой формы, собрана в центре. На одном из полюсов между стенкой и зародышевой массой имеется полярная гранула. Сходное описание приводит В.А. Герасимчик (3), указывая при этом максимальный размер ооцист 27,72×15,86 мкм, минимальный $-17,71 \times 11,17$ мкм при индексе формы 1,18-2,01, в среднем 1,59) (3). То есть, несмотря на небольшой разброс в измерениях, в других исследованиях по тем же морфологическим признакам авторы идентифицировали обнаруженные ими виды как E. vison.

По данным A.R. Pastor (29), ооцисты, идентифицированные как вид E. ichdea, по морфометрическим параметрам были следующими: длина 23,98 мкм (18,59-30,57 мкм), ширина - 18,55 мкм (13,73-23,83 мкм), индекс формы 1,01-1,60 (в среднем 1,30). Ооцисты имели эллиптическую форму, бесцветную двойную оболочку и содержали четыре спороцисты, каждая с двумя спорозоитами. Спороцисты были яйцевидными, в них присутствовали как штидовские тельца, так и остаточное тело (29). При этом A.R. Pastor указывает на достаточно большой разброс и вариабельность в измерениях ооцист (рис. 3) (29).

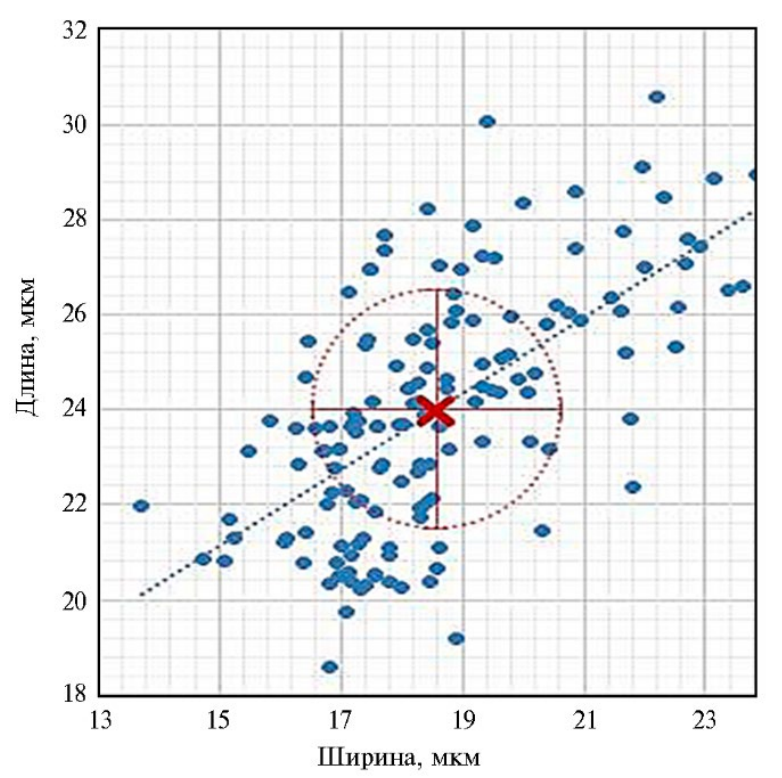

Рис. 4. Измерение формы, длины и ширины спорулированных ооцист Eimeria ictidea у черноногих хорьков (Mustela nigripes) (26). Крестиком $(\times)$ отмечено среднее значение, пунктирный овал охватывает одно стандартное отклонение от среднего.
Таким образом, мы имеем два морфологически очень схожих вида, со сравнительно одинаковой формой, размером ооцист, различающихся лишь наличием или отсутствием полярной гранулы, обнаружить которую при световой микроскопии иногда весьма сложно. Следовательно, для определения родовой и видовой принадлежности ооцист, особенно неспорулированных, необходимы молекулярногенетические исследования. Следует отметить, что вид E. ictidea методом световой микроскопией мы не выявили.

В зверохозяйстве № 1 у 47,0 \% обследованных животных была уста-

новлена моноинвазия кокцидиями. Микстинвазию, вызванную ассоциацией двух паразитов, отмечали у 39,0 \%, трех - у 14,0 \% от числа заражен- 
ных. E. vison - преобладающий вид эймерий, вызывающий моноинвазию, был обнаружен у 37 норок. При этом ЭИ среди животных, зараженных этим видом, составила 24,20\%. На втором месте по встречаемости находилась изоспора I. laidlawi (17,60 \%) (табл. 2).

Реже встречались моноинвазии, вызываемые E. furonis $(2,6 \%)$ и I. eversmanni (2,0 \%). Ранее мы сообщали, что впервые выявили вид I. eversmanni у норок в Калининградской области (25). По данным литературы, этот вид был впервые обнаружен и описан у степного хорька в Казахстане С.К. Сванбаевым в 1956 году (6). Позднее В.А. Герасимчик (3) обнаружил этот вид у норок в Республике Беларусь. Распространение вида I. eversmanni в Северо-Западном регионе до нас не изучали.

2. Экстенсивность инвазий (ЭИ) простейшими у норок в обследованных звероводческих хозяйствах Калининградской области

\begin{tabular}{|c|c|c|c|}
\hline \multirow{2}{*}{ Вид простейших } & \multicolumn{2}{|c|}{ Число животных } & \multirow{2}{*}{ ЭИ, \% } \\
\hline & обследованных & зараженных & \\
\hline \multicolumn{4}{|c|}{ Х о з я й с т в о № 1 (Багратионовский р-н, 2018 год) } \\
\hline Eimeria vison & 273 & 37 & 13,55 \\
\hline E. furonis & 273 & 4 & 1,47 \\
\hline Isospora laidlawi & 273 & 27 & 9,89 \\
\hline I. eversmanni & 273 & 3 & 1,10 \\
\hline Всего моноинвазий & 273 & 71 & 26,01 \\
\hline E. vison $+E$. furonis & 273 & 3 & 1,10 \\
\hline E. vison + I. laidlawi & 273 & 33 & 12,09 \\
\hline E. vison + I. eversmanni & 273 & 2 & 1,10 \\
\hline E. furonis + I. laidlawi & 273 & 10 & 3,66 \\
\hline E. furonis + I. eversmanni & 273 & 1 & 0,37 \\
\hline I. laidlawi + I. eversmanni & 273 & 11 & 4,03 \\
\hline Всего микстинвазий двух паразитов & 273 & 60 & 21,98 \\
\hline E. vison $+I$. laidlawi + I. eversmanni & 273 & 4 & 1,47 \\
\hline E. vison + E. furonis + I. laidlawi & 273 & 18 & 6,59 \\
\hline Всего микстинвазий трех паразитов: & 273 & 22 & 8,06 \\
\hline Всего инвазий & 273 & 153 & 56,04 \\
\hline \multicolumn{4}{|c|}{ Х о з я й с т в о № 2 (Гурьевский р-н, 2019 год) } \\
\hline E. vison & 160 & 45 & 28,13 \\
\hline I. laidlawi & 160 & 33 & 20,63 \\
\hline Всего моноинвазий & 160 & 78 & 48,75 \\
\hline E. vison $+I$. laidlawi & 160 & 6 & 3,75 \\
\hline Всего микстинвазий двух паразитов & 160 & 6 & 3,75 \\
\hline Всего инвазий & 160 & 84 & 52,50 \\
\hline \multicolumn{4}{|c|}{ Х о з я й с т в о № 3 (Зеленоградский р-н, 2019 год) } \\
\hline E. vison & 128 & 4 & 3,13 \\
\hline I. laidlawi & 128 & 41 & 32,03 \\
\hline Итого моноинвазий: & 128 & 45 & 35,16 \\
\hline E. vison + I. laidlawi & 128 & 1 & 0,78 \\
\hline Всего микстинвазий двух паразитов & 128 & 1 & 0,78 \\
\hline Всего инвазий & 128 & 46 & 35,94 \\
\hline
\end{tabular}

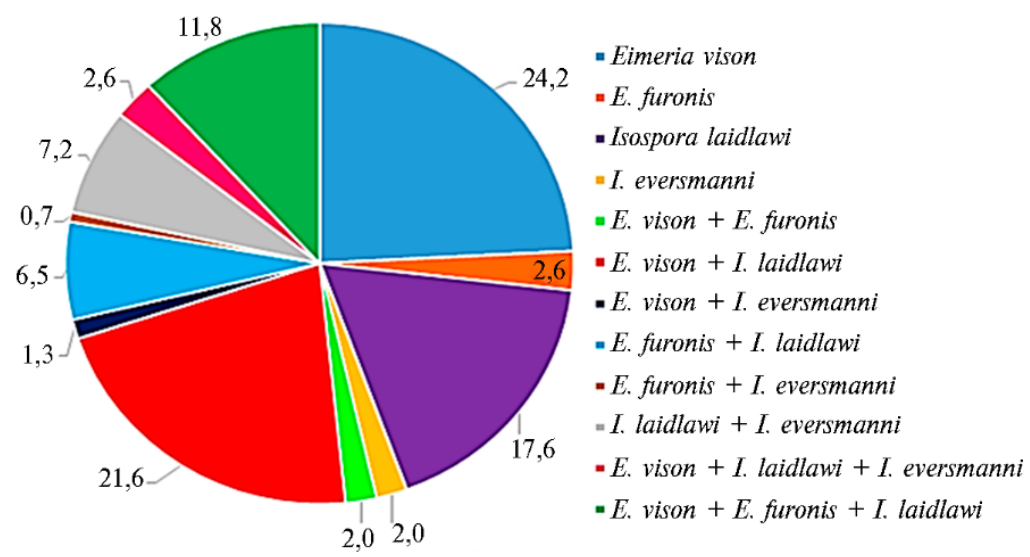

Рис. 5. Структура паразитофауны у норок, инвазированных эймериидами, в звероводческом хозяйстве № 1 (Калининградская обл., 2018 год). 
Микстинвазия двумя видами паразитов в зверохозяйстве № 1 встречалась у 39,0 \% зараженных животных и была представлена ассоциациями разных видов простейших. Микстинвазия E. vison + I. laidlawi встречалась у 33 животных, что составило 21,6 \% обследованных. Остальные ассоциации паразитов варьировались от 0,7 \% (E. furonis + I. eversmanni) до 7,2 \% (I. laidlawi + I. eversmanni) (см. табл. 2, рис. 5). Микстинвазию тремя видами паразитов зарегистрировали у 14,0 \% из числа зараженных норок. Чаще всего (у 18 животных) наблюдалась ассоциация E. vison + E. furonis + I. laidlawi (11,8 \%). У 2,6 \% зараженных норок установлено одновременное паразитирование E. vison + I. laidlawi + I. eversmanni.

В зверохозяйстве № 1 инвазия эймериидами была установлена у 23 из 42 обследованных самок (ЭИ 54,76 \%). Из 33 обследованных самцов 13, или 39,39 \%, были заражены простейшими. Установлено, что у самцов, как и у самок, преобладающим был вид эймериид E. vison, и в меньшей степени они были инвазированы I. laidlawi. Микстинвазия у взрослого поголовья норок встречалась реже, чем у молодняка. Молодняк текущего года рождения оказался наиболее инвазированным эймериидами, при этом ЭИ составила $76,50 \%$.

В зверохозяйстве № 2 из 160 обследованных норок зараженными оказались 84, что составило 52,50 \% (см. табл. 2). Среди видов кокцидий, обнаруженных у обследованных норок, были выявлены E. vison и I. laidlawi (ЭИ соответственно 28,13\% и 20,63 \%). Эймериидозы в этом хозяйстве были представлены преимущественно моноинвазиями (48,75 \% от числа обследованных норок). Микстивазию ассоциацией двух видов кокцидий обнаружили у $3,75 \%$ животных. Соотношение видов кокцидий в этом хозяйстве среди зараженных особей оказалось следующим: 53,57 \% - E. vison, $39,29 \%$ - I. laidlawi, 7,14\% - ассоциация этих видов.

В зверохозяйстве № 2 ЭИ у самок оставила 51,85\%, у самцов $44,70 \%$, у молодняка текущего года рождения - 57,35\%.

В зверохозяйстве № 3 ЭИ кокцидиями норок составила 36,0 \% (см. табл. 2). В этом хозяйстве кокцидиозы протекали преимущественно в виде моноинвазий. Среди изоспор преобладал вид I. laidlawi, обнаруженный у 41 животного (32,0 \%). Паразитирование E. vison отмечали у 3,13\% норок. Ассоциация простейших была также представлена этими двумя видами. Микстинвазию установили у одного животного $(0,78 \%$ от общего числа обследованных) (см. табл. 2). В структуре паразитофауны в этом хозяйстве преобладал вид I. laidlawi $(89,13 \%)$, реже у больных животных обнаруживали E. vison (8,70 \%), редко встречалась ассоциация этих паразитов $(2,17 \%$ от числа зараженных животных).

Отметим, что из 128 норок, обследованных нами в зверохозяйстве № 3 (см. табл. 2), бо́льшая часть (82 зверька) не были заражены простейшими. Из 56 взрослых самок только 6 животных оказались инвазироваными (ЭИ $=10,71 \%)$, и у них был обнаружен только один вид - I. laidlawi. Из 44 обследованных самцов 27 были заражены простейшими, что составило $61,36 \%$. Установлено, что у самцов, как и у самок, преобладал вид I. laidlawi, и в меньшей степени они были инвазированы E. vison. Микстинвазия у взрослого поголовья норок не встречалась. Молодняк текущего года рождения оказался наиболее инвазирован кокцидиями (ЭИ $=46,42 \%)$. У молодняка был наиболее распространен вид I. laidlawi, реже встречался вид E. vison. Такая видовая структура паразитофауны оказалась общей и для молодняка, и для взрослых самцов. Микстинвазию у молодняка диагностировали только у одного животного (E. vison + I. laidlawi).

Во всех трех обследованных зверохозяйствах ЭИ у молодняка была 
высокой. В зверохозяйствах № 1 и № 2 она оказалась выше, чем у остальных групп животных (соответственно 76,50 и 46,40 \%). В зверохозяйстве № 3 этот показатель составлял 28,30\% и был значительно ниже, чем у взрослых самцов с ЭИ $=58,70 \%$. Возможно, причиной широкого распространения инвазии стало неудовлетворительное санитарное состояние шедов, в которых содержатся самцы. Во всех хозяйствах отмечено преимущественное заражение эймериидозами самок в сравнении с самцами.

ИИ у животных во всех трех хозяйствах была низкой. У самок ИИ варьировалась в пределах 1-50, у самцов 1-80, у молодняка 1-180 ооцист.

Таким образом, во всех обследованных хозяйствах в Калининградской области у норок были обнаружены простейшие семейства Eimeriidae. По нашим наблюдениям, широкому распространению эймериидозов способствует их бессимптомное течение, затрудняющее своевременную диагностику. Молекулярно-генетические исследования показали, что последовательность фрагмента 18S рДНК длиной 383 п.н., выделенная из проб ооцист, которые методом световой микроскопии мы идентифицировали как E. vison, имела наибольшее $(99,48 \%)$ сходство с последовательностями $E$. ictidea. Однако методом копроовоскопии мы не обнаружили E. ictidea ни в одном из обследованных зверохозяйств. Это указывает на необходимость более детального молекулярно-генетического изучения эймериид, в том числе для разработки методов их выявления и идентификации с целью диагностики эймериидозов. Высокое морфологическое и генетическое сходство E. vison и E. ictidea оставляет открытой дискуссию о синонимизации этих двух видов.

В звероводческом хозяйстве № 1 мы обнаружили наибольшую ЭИ $(56,00 \%)$ и самое широкое разнообразие видов кокцидий (E. vison, E. furonis, I. laidlawi, I. eversmanni) с преобладанием моноинвазий $(47,00 \%$ обследованных животных). В меньшей степени были инвазированы норки в хозяйстве № 2 (52,50 \%), причем также с преобладанием моноинвазий $(48,75 \%)$. У обследованных норок выявлены виды E. vison и I. laidlawi. В звероводческом хозяйстве № 3 установлена наименьшая ЭИ - 35,94 \%.

В обследованных зверохозяйствах Калининградской области мы выявили различия как в инвазионной нагрузке, так и в видовом составе простейших. Более разнообразной оказалась паразитофауна на племенной звероферме (зверохозяйство № 1), где маточное поголовье ежегодно обновляется за счет приобретения животных в других хозяйствах как в Российской Федерации (Ставропольский край), так и за рубежом (в Дании). Отсутствие строгого ветеринарного контроля на границе или при перемещении пушных зверей из одних областей России в другие приводит к распространению возбудителей протозоозов, а бессимптомное течение эймериидозов затрудняет их диагностику. Ветеринарный контроль особенно важен при поступлении норок из регионов, где мониторинг инвазированности простейшими не является обязательным. В другие обследованные нами хозяйства животных не завозили, в связи с чем, по нашему мнению, обнаруженные здесь два вида паразитов - E. vison и I. laidlawi можно рассматривать в качестве эндемиков норок в Калининградской области.

Итак, во всех обследованных хозяйствах эймериидозы протекают в виде как моно-, так и микстинвазий. В целом на моноинвазии приходится $68,55 \%$ случаев, на микстинвазию двумя видами паразитов 23,67 \%, тремя видами - 7,77 \%. Преобладают два вида эймерий (Eimeria vison, E. furonis) и два вида изоспор (Isospora laidlawi, I. eversmanni с доминированием I. laidlawi). Молодняк норок более подвержен эймериидозам, чем взрослые животные. У животных текущего года рождения встречаются E. vison (18,36 \%), 
I. laidlawi $(16,32 \%)$, E. vison + I. laidlawi $(11,90 \%)$. Результаты проведенного мониторинга позволяют разрабатывать регламенты лечебно-профилактических мероприятий в звероводческих хозяйствах Калининградской области с учетом видового состава и биологии эймериид.

\section{Л ИТ Е РАТ УРА}

1. Аникиева Л.В., Аниканова В.С. Экологические адаптации паразитов к обитанию в условиях искусственного содержания хозяев. В сб.: Проблемы экологической физиологии пушных зверей. Петрозаводск, 2004, вып. 3: 161-170.

2. Полоз С.В. Ассоциативные паразитозы пушных зверей в Республике Беларусь. Актуальные проблемы патологии сельскохозяйственных животных, 2000, 2: 403-405.

3. Герасимчик В.А. Кишечные паразитозы пушных зверей (этиология, эпизоотология, патогенез, диагностика, терапия и профилактика). Автореф. докт. дис. Минск, 2008.

4. Кузовлева Л.В. Эпизоотология и меры борьбы при паразитарных болезнях пушных зверей (гельминтозы и протозоозы пушных зверей в звероводческих хозяйствах Республики Беларусь). Ветеринария. Реферативный журнал, 2002, 1: 343.

5. Вершинин И.И. Кокцицизы жсивотных и их дифференциальная диагностика. Екатеринбург, 1996.

6. Сванбаев С.К. Простейшие - возбудители болезней жсивотных Казахстана. Алма-Ата, 1967.

7. Сафиуллин Р.Т. Эймериоз и изоспороз пушных зверей и меры борьбы с ними. Российский паразитологический журнал, 2008, 2: 84-99.

8. Wilcox J.J.S. Something for everyone: a review of «The biology and identification of the Coccidia (Apicomplexa) of carnivores of the world». The American Midland Naturalist, 2019, 181(1): 143145 (doi: 10.1674/0003-0031-181.1.143).

9. Кузнецов Ю.Е. Эймериидозы норок. Современная наука: актуальные проблемы и пути их решения, 2015, 1(14): 48-50.

10. Chriél M., Hansen M.S., Petersen H.H., Holm T. Coocidiose hos mink: En undervurderet sygdom? Dansk Pelsdyravl, 2016, 2016(4): 38-38.

11. Klopfer U., Neuman M. A note on coccidiosis in minks. Refuah Veterinath, 1970, 3(27): 122-124.

12. Duszynski D.W., Kvicerova J., Seville R.S. The biology and identification of the Coccidia (Apicomplexa) of carnivores of the world. Academic Press, 2018 (doi: 10.1016/C2016-0-00320-0).

13. Нукербаева К.К. Кокцидиоз норок. Вестник сельскохозяйственной науки Казахстана, 1983, 2: $86-88$.

14. Petersen H.H., Yang R., Chriél M., Hansen M.S., Ryan U.M. Morphological and molecular characterisation of Eimeria vison-like oocysts (Apicomplexa: Eimeriidae) in farmed mink (Neovison vison) in Denmark. Parasitol. Res., 2018, 117(9): 2933-2939 (doi: 10.1007/s00436-018-5989-1).

15. Yi-Fan C., Le Y., Yin D., Jiang-Hui B. Emendation of 2 Isospora species (Apicomplexa: Eimeriidae) infecting the steppe polecat, Mustela eversmanii Lesson, 1827, in China, to the genus Cystoisospora (Apicomplexa: Sarcocystidae). Comp. Parasitol., 2012, 79: 147-152 (doi: 10.1654/4531.1).

16. Petersen H.H., Yang R., Chriél M., Hansen M.S., Ryan U.M. Morphological and molecular characterization of Eimeria vison-like oocysts (Apicomplexa:Eimeriidae) in farmed mink (Neovison vison) in Denmark. Parasitol. Res., 2018, 117(9): 2933-2939 (doi: 10.1007/s00436-018-5989-1).

17. Sledge D.G., Bolin S.R., Lim A., Kaloustian L.L. Outbreaks of severe enteric disease associated with Eimeria furonis infection in ferrets (Mustela putorius furo) of 3 densely populated groups. Journal of the American Veterinary Medical Association 2011, 239(12): 1584-1588 (doi: 10.2460/javma.239.12.1584).

18. Кузнецов Ю.Е. Паразитозы пушных зверей в хозяйствах Северо-Западного региона Российской Федерации (меры борьбы и профилактика). Докт. дис. СПб, 2020.

19. Герасимчик В.А., Зыбина О.Ю. Морфобиологическая характеристика эймериид норок. Ученые записки УО ВГАВМ, 2010, 46(1-1): 101-104.

20. Белова Л.М., Гаврилова Н.А., Пудовкин Д.Н., Токарев А.Н., Кузнецов Ю.Е. Жидкость для диагностики ооцист кокцидий, цист балантидий и жиардий, яиц гельминтов разных классов, клещей, насекомых, их отдельных стадий развития. Пат. RU 2472154 C2 (PФ) МПК G01N33/48 A61D99/00. ФГБОУ ВО «СПБГАВМ» (РФ). № 2010153464/13. Заявл. 27.12.10. Опубл. 01.10.13. Бюл. № 1.

21. Белова Л.М., Рязанцева Л.Т., Гаврилова Н.А., Кузнецов Ю.Е., Петрова М.С. «Чашка Петрu» Пат. RU № 180046 U1 (РФ) МПК: C12M 1/22, ФГБОУ ВО СПБГАВМ (РФ) № 2017139607. Заявл. 14.11.2017. Опубл. 31.05.2018 г. Бюл. № 23.

22. Pellerdy L.P. Coccidia and coccidiosis. Budapest, 1974.

23. Kuznetsov Y.E., Engashev S.V., Engasheva E.S., Nikonov I.N., Kuznetsova N.V. Microbial community studying of the dogs' gastrointestinal tract by the T-RFLP molecular genetic method 
and assessing the natural resistance of animals. Research Journal of Pharmaceutical, Biological and Chemical Sciences, 2018, 9(5): 1652-1660.

24. Carreno R.A., Barta J.R. An Eimeriid origin of isosporoid coccidia with Stieda bodies as shown by phylogenetic analysis of small subunit ribosomal RNA gene sequences. Journal of Parasitology, 1999, 85(1): 77-83.

25. Кузнецов Ю.Е., Белова Л.М., Гаврилова Н.А., Мкртчян М.Э., Сидоренко К.А., Муромцев А.Б. Особенности диагностики и патоморфологии эймериидозов норок в зверохозяйствах Северо-Западного региона Российской Федерации. Сельскохозяйственная биология, 2020, 55(2): 378-393 (doi: 10.15389/agrobiology.2020.2.378rus).

26. Carreno R.A., Schnitzler B.E., Jeffries A.C., Tenter A.M., Johnson A.M., Barta J.R. Phylogenetic analysis of coccidia based on $18 \mathrm{~S}$ rDNA sequence comparison indicates that Isospora is most closely related to Toxoplasma and Neospora. Journal of Eukaryotic Microbiology, 1998, 45(2): 184188 (doi: 10.1111/j.1550-7408.1998.tb04523.x).

27. Hikosaka K., Nakai Y., Watanabe Y., Tachibana S., Arisue N., Palacpac N.M., Toyama T., Honma H., Horii T., Kita K., Tanabe K. Concatenated mitochondrial DNA of the coccidian parasite Eimeria tenella. Mitochondrion, 2011, 11(2): 273-278 (doi: 10.1016/j.mito.2010.10.003).

28. Ogedengbe J.D., Hanner R.H., Barta J.R. DNA barcoding identifies Eimeria species and contributes to the phylogenetics of coccidian parasites (Eimeriorina, Apicomplexa, Alveolata). International Journal for Parasitology, 2011, 41(8): 843-850 (doi: 10.1016/j.ijpara.2011.03.007).

29. Pastor A.R. Investigating enteric coccidiosis in the black-footed (Mustela nigripes) and domestic ferret (Mustela putorius furo). PhD. University of Guelph, 2017.

30. Cavalier-Smith T. Gregarine site-heterogeneous 18S rDNA trees, revision of gregarine higher classification, and the evolutionary diversification of Sporozoa. European Journal of Protistology, 2014, 50(5): 472-495 (doi: 10.1016/j.ejop.2014.07.002).

31. Wang Q.G., Garrity M., Tiedje J.M., Cole J.R., Naïve Bayesian classifier for rapid assignment of rRNA sequences into the new bacterial taxonomy. Applied and Environmental Microbiology, 2007, 73(16): 5261-5267 (doi: 10.1128/AEM.00062-07).

32. Klockiewicz M., Jakubowski T., Janecka E., Długosz E. Preliminary epidemiological survey of infections by intestinal parasites in selected mink farms in Poland. Medycyna weterynaryjna, 2013, 69(7): 444-447.

\footnotetext{
1ФГБОУ ВО Санкт-Петербургский государственный университет ветеринарной медицины, 196084 Россия, г. Санкт-Петербург, ул. Черниговская, 5, e-mail: Fish2017@yandex.ru $\bowtie$, larissabelova2010@yandex.ru, nadezhda.gavrilova65@mail.ru, n.kuznetcova2018@mail.ru;

${ }^{2}$ Калининградский филиал

ФГБОУ ВО Санкт-Петербургский государственный

аграрный университет,

238630 Россия, Калининградская обл., г. Полесск, ул. Советская, 10,

e-mail: muromtsev.a@mail.ru;

ЗФГБОУ ВО Калининградский институт переподготовки

кадров агробизнеса,

236038 Россия, г. Калининград, ул. Молодой Гвардии, 2,

e-mail: alexandrdr1990@gmail.com
}

Sel'skokhozyaistvennaya biologiya [Agricultural Biology], 2021, V. 56, № 4, pp. 718-729

\title{
EPIZOOTIC MONITORING OF PROTOZOOZES IN THE FUR FARMS OF THE KALININGRAD REGION (2018-2020)
}

\author{
Yu.E. Kuznetsov ${ }^{1}$, L.M. Belova ${ }^{1}$, N.A. Gavriloval, N.V. Kuznetsova ${ }^{1}$, A.B. Muromcev' ${ }^{2}$, \\ A.Yu. Efremov ${ }^{3}$
}

${ }^{1}$ Saint-Petersburg State University of Veterinary Medicine, 5, ul. Chernigovskaya, St. Petersburg, 196084 Russia, e-mail Fish2017@yandex.ru ( $₫$ corresponding author), larissabelova2010@yandex.ru, nadezhda.gavrilova65@mail.ru, n.kuznetcova2018@mail.ru;

${ }^{2}$ Kaliningrad Branch of the St. Petersburg State Agrarian University, 10, ul. Sovetskaya, Polessk, Kaliningrad Province, 238630 Russia, e-mail muromtsev.a@mail.ru;

${ }^{3}$ Kaliningrad Institute for Retraining Agribusiness Personnel, 2, ul. Molodoi Gvardii, Kaliningrad, 236038 Russia, e-mail alexandrdr1990@gmail.com

ORCID:

Kuznetsov Yu.E. orcid.org/0000-0001-9095-7049

Belova L.M. orcid.org/0000-0003-4473-1940

Gavrilova N.A. orcid.org/0000-0001-5651-5976

The authors declare no conflict of interests

Kuznetsova N.V. orcid.org/0000-0002-3149-1557

Muromcev A.B. orcid.org/0000-0002-2456-7023

Efremov A.Yu. orcid.org/0000-0003-3325-8490 


\begin{abstract}
Parasitic diseases are widespread in fur-bearing animals, especially in minks. Coccidiidoses occupy a special place among invasive diseases, as they often occur without any symptoms and in some cases are not timely diagnosed. Despite the mild clinical manifestation of invasion, it causes serious damage to animal health and significant economic damage to fur-bearing animal farms. After analyzing the literature data, it became clear that the distribution of eimerioses of fur-bearing animals in the Kaliningrad region has not been studied well enough. In particular, there is no information about the prevalence rates, invasion intensity, and age dynamics of the mink eimeriosis in the fur farms of the region. The purpose of this work was to study the epizootic situation on mink (Mustela vison, Linnaeus, 1761, Neovison vison Schreber, 1777) coccidiidoses in fur-bearing animal farms in the Kaliningrad region. Investigations were performed in three fur-bearing animal farms of the Kaliningrad region. The species composition of protozoa in minks was determined by the morphological features of coccidia and by deep sequencing of the $18 \mathrm{~S}$ rDNA V4 region. OTUs (operational taxonomic units) revealed by the bioinformatic analysis were used to establish the taxonomic affiliation of pathogens which confirmed the results of light microscopy. In analyzing the obtained results and choosing research methods, the age, sex of the animals, as well as housing and feeding conditions were taken into account. Young minks of 5-6 months and adult livestock, 1-2 year-old females and males, were surveyed. In total, 561 animals were examined in three farms, including farm $1-273$ minks (198 young animals, 75 adults - 33 males and 42 females); farm $2-160$ minks (68 young animals, 92 adults -44 males and 48 females), and farm $3-128$ minks (28 young animals, 100 adults -44 males and 56 females). In all the farms surveyed, we found the protozoan of the Eimeriidae family. The greatest prevalence rates $(56 \%)$ and the widest variety of coccidia species occurred in the animals of farm 1 under the invasion of two eimeria, Eimeria vison and E. furonis, and two isospores, Isospora laidlawi and I. eversmanni (the I. eversmanni we have earlier identified in minks in the Kaliningrad region for the first time). In all fur farms in the Kaliningrad region, eimerioses more often occur as mono invasions. In mixed invasions, $68.55 \%$ were two-parasite invasions, $23.67 \%$ were three-parasite invasions. Young minks are more susceptible to eimeriidoses than adults. In the animals of the current year of birth, E. vison (18.36\%), I. laidlawi (16.32\%), and E. vison + I. laidlawi (11.90\%) prevailed.
\end{abstract}

Keywords: Mustela vison, Neovison vison, minks, Eimeria vison, Eimeria furonis, Isospora laidlawi, Isospora eversmanni, mono invasion, mixed invasion, invasion extensity, invasion intensity, fur farms, Kaliningrad region. 